\title{
Essential oils of Eplingiella fruticosa populations: chemical, antioxidant, and cytotoxic
}

\section{analyses}

Óleos essenciais de populações de Eplingiella fruticosa: análise química e atividades antioxidante e citotóxica

Aceites esenciales de poblaciones de Eplingiella fruticosa: análisis químico y actividades antioxidantes y citotóxicas

\author{
Jéssika Andreza Oliveira Pinto \\ ORCID: https://orcid.org/0000-0003-2496-5109 \\ Universidade Federal de Sergipe, Brasil \\ E-mail: jessika-andreza@hotmail.com \\ Anne Karoline de Souza Oliveira \\ ORCID: https://orcid.org/0000-0001-8145-0684 \\ Universidade Federal de Sergipe, Brasil \\ E-mail: karol_olyveira@outlook.com \\ Edmilson Willian Propheta dos Santos \\ ORCID: https://orcid.org/0000-0001-9291-9564 \\ Universidade Federal de Sergipe, Brasil \\ E-mail: willianpropheta@gmail.com \\ Ana Mara de Oliveira e Silva \\ ORCID: https://orcid.org/0000-0003-0831-8833 \\ Universidade Federal de Sergipe, Brasil \\ E-mail: anamaraufs@gmail.com \\ Arie Fitzgerald Blank \\ ORCID: https://orcid.org/0000-0003-2888-2239 \\ Universidade Federal de Sergipe, Brasil \\ E-mail: arie.blank@gmail.com \\ Cristiane Bani Corrêa \\ ORCID: https://orcid.org/0000-0001-8954-6285 \\ Universidade Federal de Sergipe, Brasil \\ E-mail: crisbani@gmail.com \\ Paulo Cesar Lima Nogueira \\ ORCID: https://orcid.org/0000-0003-0832-1047 \\ Universidade Federal de Sergipe, Brasil \\ E-mail: pclnogueira@uol.com.br \\ Maria de Fátima Arrigoni-Blank \\ ORCID: https://orcid.org/0000-0002-4907-505X \\ Universidade Federal de Sergipe, Brasil \\ E-mail: fatima.blank@gmail.com
}

\begin{abstract}
This study investigates the variations in the chemical profiles and biological activities (antioxidant and cytotoxic) of Eplingiella fruticosa from the state of Sergipe, an endemic species from the Northeast region of Brazil. The essential oils were extracted from six populations by hydrodistillation and analyzed by GC/MS-FID. Cluster analysis was performed with the data of the constituents of the essential oils, and then a dissimilarity matrix, based on Euclidean distances, and a dendrogram, through the Ward clustering method, were constructed. The antioxidant activity of the essential oils was tested by different assays (DPPH, ABTS, $\beta$-carotene, and FRAP), and cytotoxic activity was tested by the SRB assay. The compounds found in greater amounts were $\alpha$-pinene, $\beta$-pinene, 1,8 -cineole, camphor, borneol, $\delta$-elemene, $\alpha$-cubebene, $\alpha$-ylangene, (E)-caryophyllene, germacrene $\mathrm{D}$, bicyclogermacrene, trans-calamenene, spathulenol, caryophyllene oxide, and viridiflorol. These compounds defined the formation of two groups. The first group was composed of the populations of São Cristóvão, Itaporanga, Japaratuba, and Malhada dos Bois municipalities and was characterized by the presence of the monoterpene camphor (8.39-11.27\%) as the compound of greatest concentration in relation to the other municipal areas. The second group was composed of the populations of Moita Bonita and Pirambu municipalities and was characterized by the major presence of the sesquiterpene bicyclogermacrene $(7.45 \%$ and $10.98 \%)$. The plants exhibited weak effects in terms of antioxidant activity; however, the essential oil showed significant toxicity for the lines A549 (51.00\% cell viability) in the population of Japaratuba,
\end{abstract}


and B16F10 (64.94\% cell viability) in Malhada dos Bois. The observations of this study may open a way to optimize the use of the E. fruticosa populations in relation to their cytotoxic properties.

Keywords: Chemical composition; Eplingiella fruticosa; Biological activities.

\section{Resumo}

Este estudo investiga as variações nos perfis químicos e atividades biológicas (antioxidante e citotoxicidade) de Eplingiella fruticosa do Estado de Sergipe, uma espécie endêmica da região nordeste do Brasil. Os óleos essenciais de seis populações foram extraídos por hidrodestilação e analisados por CG/EM-DIC. Com os dados dos constituintes dos óleos essenciais foi realizada uma análise de agrupamento, e posteriormente, foi construída uma matriz de dissimilaridade, baseada nas distâncias euclidiana, e um dendograma, através do método de agrupamento de Ward. A atividade antioxidante dos óleos essenciais foi testada por diferentes ensaios (DPPH, ABTS, $\beta$-caroteno e FRAP) e a atividade citotóxica foi feita pelo ensaio SRB. Os compostos encontrados em maiores quantidades foram: $\alpha$-pineno, $\beta$ pineno, 1,8-cineol, cânfora, borneol, $\delta$-elemeno, $\alpha$-cubebeno, $\alpha$-ylangeno, (E)-cariofileno, germacreno D, biciclogermacreno, trans-calameneno, espatulenol, óxido de cariofileno e viridiflorol. Esses compostos definiram a formação de dois grupos. O primeiro grupo foi constituído pelas populações de São Cristóvão, Itaporanga, Japaratuba e Malhada dos Bois e caracterizou-se pela presença do monoterpeno cânfora $(8,39-11,27 \%)$ como composto de maior teor em relação aos demais municípios. O segundo grupo foi constituído pelas populações de Moita Bonita e Pirambu e se caracterizou pela presença majoritária do sesquiterpeno biciclogermacreno $(7,45 \%$ e $10,98 \%)$. As plantas apresentaram efeitos fracos em termos de atividade antioxidante, porém o óleo essencial mostrou toxicidade significativa para as linhagens A549 (51,00\% da viabilidade celular) na população de Japaratuba e B16F10 (64,94,6\% da viabilidade celular) em Malhada dos Bois. As observações deste estudo podem abrir caminho para otimizar o uso das populações de $E$. fruticosa em relação às suas propriedades citotóxicas.

Palavras-chave: Composição química; Eplingiella fruticosa; Atividades biológicas.

\section{Resumen}

Este estudio investiga las variaciones en los perfiles químicos y actividades biológicas (antioxidante y citotoxicidad) de Eplingiella fruticosa del estado de Sergipe, una especie endémica del noreste de Brasil. Los aceites esenciales de seis poblaciones fueron extraídos por hidrodestilación y analizados por GC/EM-DIC. Con los datos de los constituyentes de los aceites esenciales se realizó un análisis de conglomerados y posteriormente se construyó una matriz de disimilitudes, a partir de distancias euclidianas, y un dendrograma, utilizando el método de conglomerados de Ward. La actividad antioxidante de los aceites esenciales se evaluó mediante diferentes ensayos (DPPH, ABTS, $\beta$ caroteno y FRAP) y la actividad citotóxica se realizó mediante el ensayo SRB. Los compuestos encontrados en mayores cantidades fueron: $\alpha$-pineno, $\beta$-pineno, 1,8-cineol, alcanfor, borneol, $\delta$-elemeno, $\alpha$-cubeben, $\alpha$-ylangen, (E)cariofileno, germacreno D, biciclogermacreno, trans-calameneno, espatulenol, óxido de cariofileno y viridiflorol. Estos compuestos definieron la formación de dos grupos. El primer grupo lo constituyeron las poblaciones de São Cristóvão, Itaporanga, Japaratuba y Malhada dos Bois y se caracterizó por la presencia del alcanfor monoterpeno (8,39-11,27\%) como compuesto de mayor contenido en relación a los demás municipios. El segundo grupo estuvo constituido por las poblaciones de Moita Bonita y Pirambu y se caracterizó por la presencia mayoritaria de biciclogermacreno sesquiterpeno $(7,45 \%$ y $10,98 \%)$. Las plantas mostraron efectos débiles en términos de actividad antioxidante, pero el aceite esencial mostró toxicidad significativa para las líneas A549 (51,00\% de viabilidad celular) en la población de Japaratuba y B16F10 (64,94,6\% de viabilidad celular) en Malhada de los Bueyes. Las observaciones de este estudio pueden abrir el camino para optimizar el uso de poblaciones de E. fruticosa en relación con sus propiedades citotóxicas.

Palabras clave: Composición química; Eplingiella fruticosa; Actividades biológicas.

\section{Introduction}

Plants have been an important source of treatments for illnesses for thousands of years. According to the World Health Organization (WHO), 80\% of the world's population depends on folk medicine for their basic health needs. Awareness of traditional knowledge and of medicinal plants can play a fundamental role in the investigation and discovery of the natural resources of plants. This empirical knowledge helps the pharmaceutical industry to develop new medications that will be used in the treatment of various diseases (Sivakumar and Balasubramanian, 2020; Jamshidi-Kia et al., 2018).

Lamiaceae, with around 250 genera and more than 7,000 species distributed throughout the world, is among the largest plant families. This family is considered an important source of essential oils with analgesic, antioxidant, and anticancer properties (Mesquita et al., 2019; Uritu et al., 2018; Nieto, 2017). The genus Hyptis, the representative of the family with the largest number of species in Brazil, underwent taxonomic modifications after a recent review of the subtribe Hyptidinae, when 
a considerable part of its species were redistributed in eleven genera, including the genus Eplingiella (Harley and Pastore, 2012).

Eplingiella fruticosa, popularly known as "alecrim-de-vaqueiro", is a medicinal and aromatic plant distributed over the coast of the Northeast region of Brazil. The species is used in folk medicine for treating pain through infusion of its leaves. Some studies have shown that its essential oil has anti-hyperalgesic effects and effects against neurodegenerative diseases (Oliveira Melo et al., 2020; Beserra-Filho et al., 2019).

Essential oils are mixtures of volatile compounds obtained from medicinal and aromatic plants that exhibit diverse activities, e.g., antioxidant activity, performed by chemical constituents that avoid oxidative damage and may act to prevent various degenerative diseases, including cancer (Jemli et al., 2016; Sousa et al., 2013). Cancer is an important health problem and one of the main causes of death throughout the world. In spite of advances, there are no effective drugs for curing most cancers. That requires the development of new drugs with high efficiency, low toxicity, low environmental impact, and low cost. There is interest in identifying metabolites of medicinal plants with the aim of developing anticancer herbal medicines or adjuvants for conventional therapies (Tariq et al., 2017; Bray et al., 2013). Therefore, the aim of this study was to characterize the essential oil of native populations of E. fruticosa found in the state of Sergipe, Brazil, and investigate its antioxidant and cytotoxic effect.

\section{Methodology}

\subsection{Plant material}

Plants were collected from six populations of E. fruticosa in the following municipalities of the state of Sergipe:

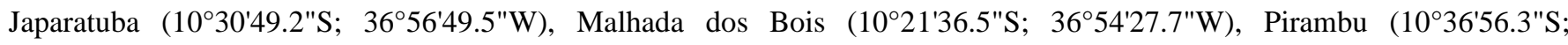

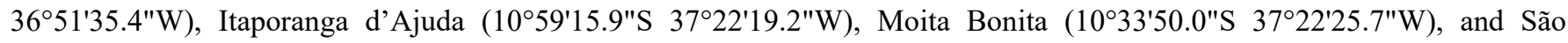
Cristóvão $\left(10^{\circ} 57^{\prime} 43.9^{\prime \prime S} 37^{\circ} 09^{\prime} 49.8^{\prime \prime W}\right)$. These collections were made according to the results found by Silva et al. (2017; 2018).

\subsection{Extraction and identification of the chemical composition of the essential oils}

The leaves collected were taken to the Department of Agronomic Engineering of the Federal University of Sergipe, where the material was dried in a forced air circulation laboratory oven at $40^{\circ} \mathrm{C}$ for five days. The essential oil was extracted by hydrodistillation in a modified Clevenger apparatus (Guenther, 1972). Samples of $70 \mathrm{~g}$ of dry leaves were distilled for 140 minutes (Ehlert et al., 2006). The essential oils were collected and stored in amber bottles at $-20^{\circ} \mathrm{C}$ up to analysis of chemical composition.

The components of the essential oils were analyzed using GC-MS/GC-FID (GC-2010 Plus; GCMS-QP2010 Ultra, Shimadzu Corporation, Kyoto, Japan) equipped with an AOC-20i automatic sampler (Shimadzu). Separations were made using a fused silica capillary column Rtx®-5MS Restek (5\% - diphenyl / 95\% - dimethyl polysiloxane) of $30 \mathrm{~m} \times 0.25 \mathrm{~mm}$ internal diameter (i.d.), $0.25-\mu \mathrm{m}$ film thickness, in a constant helium flow (99.999\%) at a rate of $1.2 \mathrm{~mL} \cdot \mathrm{min}^{-1}$. An injection volume of $0.5 \mu \mathrm{L}\left(5 \mathrm{mg} \cdot \mathrm{mL}^{-1}\right)$ was used, with a split ratio of 1:10. Programming of oven temperature began at $50^{\circ} \mathrm{C}$ (isotherm for 1.5 min), with an increase of $4{ }^{\circ} \mathrm{C} \cdot \mathrm{min}^{-1}$ at $200^{\circ} \mathrm{C}$, followed by $10^{\circ} \mathrm{C} \cdot \mathrm{min}^{-1}$ up to $250^{\circ} \mathrm{C}$, finishing with an isotherm of $5 \mathrm{~min}$ at $250^{\circ} \mathrm{C}$ (Silva et al., 2018).

The GC-MS and GC-FID data were simultaneously acquired using a detector separation system. The flow split ratio was $4: 1$ (MS:FID). A $0.62 \mathrm{~m} \times 0.15 \mathrm{~mm}$ i.d. restriction tube (capillary column) was used to connect the splitter to the MS detector; and a $0.74 \mathrm{~m} \times 0.22 \mathrm{~mm}$ i.d. restriction tube was used to connect the splitter to the FID detector. The injector temperature was $250^{\circ} \mathrm{C}$ and the temperature of the ion source was $200^{\circ} \mathrm{C}$. The ions were generated at $70 \mathrm{eV}$ at a scanning 
speed of 0.3 fragments (scans) $\mathrm{s}^{-1}$ detected in the interval of 40-350 Da. The FID temperature was adjusted to $250^{\circ} \mathrm{C}$, and the gases supplied to the FID were synthetic air, hydrogen, and helium at flow rates of 30, 300, and $30 \mathrm{~mL}^{\mathrm{min}}{ }^{-1}$, respectively (Silva et al., 2018).

The constituents of the essential oils were identified based on comparison of the retention indices in the literature (Adams, 2007). For the retention index, the equation of Van Den Dool and Kratz (1963) was used in relation to a homologous series of n-alkanes (nC9 - nC18). Three equipment libraries, from WILEY8, NIST107, and NIST21, were also used, which allowed comparison of the spectra data with those contained in the libraries, using a similarity index of $80 \%$.

\subsection{Antioxidant activity}

For evaluation of the antioxidant capacity of E. fruticosa, $1 \mu \mathrm{L} \cdot \mathrm{mL}^{-1}$ stock solutions of essential oil were prepared, diluted in ethanol, and tested in different assays (Couto et al., 2019). The assays were conducted in the Food Science Laboratory of the Federal University of Sergipe.

\subsubsection{DPPH (2,2-diphenyl-1-picrylhydrazyl)}

The essential oils of E. fruticosa were evaluated by the DPPH radical scavenging assay adapted from Brand-Williams et al. (1995). Concentrations of $50 \mu \mathrm{L}$ of sample were added to $150 \mu \mathrm{L}$ of ethanol solution of DPPH at $6 \times 10^{-5}$ mol.L $\mathrm{L}^{-1}$, which were placed in microplates. The tests were accompanied by a control (reaction medium without the oil). After 30 minutes of rest in a dark environment, reduction of the DPPH radical was measured at a wavelength of 515 nm in a plate reader (Biotek, Synergy Mx). Reduction in the absorbance (Abs) values of the samples was correlated with that of the control, and the DPPH radical scavenging percentage was established, expressed by the following equation: scavenging $\%=\left[\left(\mathrm{Abs}_{\mathrm{control}}-\mathrm{Abs}_{\mathrm{sample}}\right) /\right.$ $\left.\mathrm{Abs}_{\text {control }}\right] \mathrm{x}$ 100. The results of inhibition of the DPPH radical were expressed in the DPPH radical scavenging percentage.

\subsubsection{ABTS [2,2-azino-bis (3-ethylbenzothiazoline-6-sulfonic acid)]}

For the assay regarding the antioxidant against the ABTS radical, the methodology described by Re et al. (1999), with adaptations, was used. The ABTS radical cation was prepared from the reaction of $5 \mathrm{~mL}$ of a $7 \mathrm{mM}$ ABTS solution in $88 \mu \mathrm{L}$ of a $140 \mathrm{mM}$ potassium persulfate $\left(\mathrm{K}_{2} \mathrm{~S}_{2} \mathrm{O}_{8}\right)$ solution, incubated in the absence of light for $16 \mathrm{~h}$. After that time, the ABTS solution was diluted in ethanol until reaching a solution with absorbance of $0.70 \mathrm{~nm} \pm 0.05 \mathrm{~nm}$ at $734 \mathrm{~nm}$. In a microplate, 30 $\mu \mathrm{L}$ of the sample was added to $300 \mu \mathrm{L}$ of the ABTS radical solution. The determinations were accompanied by a control (reaction medium without oil). Reduction in the absorbance values of the samples was correlated with the absorbance of the control, and the ABTS radical scavenging percentage was established, expressed by the following equation: scavenging \% $=$ $\left[\left(\mathrm{Abs}_{\text {control }}-\mathrm{Abs}_{\text {sample }}\right) / \mathrm{Abs}_{\text {control }}\right] \mathrm{x}$ 100. The results of ABTS radical inhibition were expressed in ABTS radical scavenging percentage.

\subsection{3 $\beta$-carotene/linoleic acid}

The $\beta$-carotene/linoleic acid co-oxidation method was performed according to the methodology described by Miller (1971), with some modifications. To prepare the emulsion, $10 \mu \mathrm{L}$ of linoleic acid, $200 \mu \mathrm{L}$ of $\beta$-carotene solution (2 mg.mL $\left.{ }^{-1}\right)$, and $50 \mu \mathrm{L}$ of Tween 20 were dissolved in $500 \mu \mathrm{L}$ of chloroform. The solution was placed in a gas exhaust hood until complete evaporation of the chloroform, and $25 \mathrm{~mL}$ of distilled water, previously saturated with oxygen for $30 \mathrm{~min}$, was added. Then, 35 $\mu \mathrm{L}$ of the sample and $250 \mu \mathrm{L}$ of the emulsifier solution were pipetted in the plate. The same experimental procedure was performed with ethyl alcohol as a control. Absorbance was read at $470 \mathrm{~nm}$ in a spectrophotometer at time $0 \mathrm{~h}$, and then the plate was incubated in the dark at $50^{\circ} \mathrm{C}$ for $2 \mathrm{~h}$. After that procedure, a new reading was made at the same wavelength. The decay of optical density of the control ( $\left.\mathrm{Abs}_{\text {initial }}-\mathrm{Abs}_{\text {final }}\right)$ was considered as $100 \%$ oxidation. From this relation, the decrease 
in reading of absorbance of the samples was correlated with the control, thus establishing the percentage of oxidation protection of the samples by the following equation: \% of oxidation protection $=100-\left[\left(\mathrm{Abs}_{\text {sample } \mathrm{x}} 100\right) / \mathrm{Abs}\right.$ control $]$.

\subsubsection{FRAP}

For determination of the ferric reducing capacity of the essential oils of E. fruticosa, the methodology described by Singhal et al. (2014) was used. A $9 \mu \mathrm{L}$ aliquot of the sample was pipetted in a microplate, and then $27 \mu \mathrm{L}$ of distilled water and $270 \mu \mathrm{L}$ of the FRAP reagent were added. The FRAP reagent is prepared shortly before the test, mixing $10 \mathrm{~mL}$ of $0.3 \mathrm{M}$ acetate buffer, $10 \%(1 \mathrm{~mL}$ ) of a $10 \mathrm{mM}$ Tripyridyl-S-triazine (TPTZ) solution, and $1 \mathrm{~mL}(10 \%)$ of a $20 \mathrm{mM}$ ferric chloride aqueous solution. The plate was incubated at $37^{\circ} \mathrm{C}$ for $30 \mathrm{~min}$ and a reading was made at $595 \mathrm{~nm}$. The same experimental procedure was performed with ethyl alcohol as a control. A ferrous sulfate $\left(\mathrm{FeSO}_{4}\right)$ curve was prepared at concentrations from 125-1500 $\mu \mathrm{M}$, exposed to the same conditions of the sample. The results were expressed in $\mu \mathrm{M}$ of equivalents of ferrous sulfate/mL.

\subsection{Cytotoxicity}

The assays were conducted in the Cancer and Leishmania Biology and Immunology Laboratory of the Federal University of Sergipe. The cell lines of lung cancer (A549), melanoma (B16F10), and glioma (C6) were acquired at the Federal University of Rio de Janeiro. The cells were cultivated in a humidified incubator at $37^{\circ} \mathrm{C}$ in $5 \% \mathrm{CO}_{2}$ in Dulbecco's Modified Eagle Medium (DMEM) supplemented with 10\% fetal bovine serum (FBS) and 1\% antibiotic (10,000 U/mL penicillin, $10,000 \mathrm{mg} / \mathrm{mL}$ streptomycin).

The cytotoxic activity of the essential oils of E. fruticosa was determined by the Sulforhodamine B (SRB) assay, following a protocol adapted from Kasinski et al. (2015) and Orellana \& Kasinski (2016). The cell lines A549, B16F10, and C6 were sown in $200 \mu \mathrm{L}$ of medium $\left(10^{4}\right.$ cells $\left./ \mathrm{ml}\right)$ in 96-well cell culture plates. After $24 \mathrm{~h}$, the cells were treated with the oils at a concentration of $50 \mu \mathrm{M}$ for $72 \mathrm{~h}$. Dimethyl sulfoxide (DMSO, 0.05\%) was used as a vehicle control and $10 \mu \mathrm{M}$ Doxorubicin Hydrochloride was used as a positive control.

After the treatment, the supernatant was discarded and the cells were fixed with $100 \mu \mathrm{L}$ of $30 \%$ trichloroacetic acid for $1 \mathrm{~h}$ at $4{ }^{\circ} \mathrm{C}$ and stained with $100 \mu \mathrm{L}$ of SRB $(0.057 \% \mathrm{w} / \mathrm{v})$ for $30 \mathrm{~min}$. The plate was washed with $1 \%$ acetic acid three times to remove excess stain, and the intracellular stain was dissolved in $200 \mu \mathrm{L}$ of TRIS (10 mM; pH 10.5) for $30 \mathrm{~min}$. Absorbance was read in a microplate reader at $510 \mathrm{~nm}$. The absorbance was converted into growth inhibition by the following equation:

$$
\% \text { growth inhibition }=\frac{A b s(\text { treated cells })-A b s \text { (negative control })}{A b s(\text { positive control })-A b s(\text { negative control })} \times 100
$$

\subsection{Statistical analysis}

Analysis of variance (ANOVA version 5.6) was performed on the data of chemical characterization, and the mean values were compared by the Scott-Knott test $(p \leq 0.05)$ (Ferreira, 2011). From the data of the constituents of the essential oils, two multivariate analyses were performed, principal component analysis and cluster analysis, using the Statistica ${ }^{\circledR}$ software. Graphs with the mean values of the concentrations of the chemical constituents and standard deviations for each chemical group were obtained with the Graph Pad Prism ${ }^{\circledR}$ software.

ANOVA was performed on the data of the antioxidant and cytotoxicity activity analyses (Ferreira, 2011). The data were expressed in mean \pm SE (standard error) and Tukey's test $(p<0.05)$. All the tests were performed in triplicate. 


\section{Results}

The concentrations of the main compounds of the essential oil varied significantly among the populations of $E$. fruticosa (Table 1). Among the populations, 51 compounds were found, and the following compounds were detected in greater quantities: $\alpha$-pinene, $\beta$-pinene, 1,8-cineole, camphor, borneol, $\delta$-elemene, $\alpha$-cubebene, $\alpha$-ylangene, (E)-caryophyllene, germacrene D, bicyclogermacrene, trans-calamenene, spathulenol, caryophyllene oxide, and viridiflorol. These compounds defined the formation of two groups (Figure 1). The first group was formed by the populations of São Cristóvão, Itaporanga d'Ajuda, Japaratuba, and Malhada dos Bois and was characterized by the presence of the monoterpene camphor (8.39-11.27\%) as the compost of greatest concentration in relation to the other municipalities (Figure 2). The second group was constituted by the populations of Moita Bonita and Pirambu and was characterized by the major presence of the sesquiterpene bicyclogermacrene $(7.45 \%$ and $10.98 \%$ ) (Figure 2$)$.

According to principal component analysis (Figure 3), the first principal component represented $60.95 \%$ of the total variation and was positively related to the compounds $\alpha$-pinene, $\beta$-pinene, 1,8 -cineole, trans-calamenene, and caryophyllene oxide; and negatively correlated with $\delta$-elemene, $(\mathrm{E})$-caryophyllene, germacrene $\mathrm{D}$, and bicyclogermacrene. The second principal component represented $17.22 \%$ of the total variation and was positively related to the compounds $\alpha$-cubebene and viridiflorol, and negatively correlated with the compounds camphor and borneol.

Table 1. Concentrations (\%) of the main chemical compounds found in the essential oil of E. fruticosa populations in the state of Sergipe, Brazil.

\begin{tabular}{|c|c|c|c|c|c|c|c|c|}
\hline \multirow[t]{2}{*}{ Compound } & \multirow[b]{2}{*}{ IRR-o } & \multirow[b]{2}{*}{ IRR-1 } & \multicolumn{6}{|c|}{ Populations / Municipilaties } \\
\hline & & & São Cristóvão & Pirambu & Moita Bonita & Malhada dos Bois & Japaratuba & $\begin{array}{c}\text { Itaporanga } \\
\text { D'Ajuda }\end{array}$ \\
\hline$\alpha$-Pinene & 934 & 932 & $3.40 \mathrm{c}$ & $1.69 \mathrm{f}$ & $1.78 \mathrm{e}$ & $5.28 \mathrm{a}$ & $4.32 \mathrm{~b}$ & $2.85 \mathrm{~d}$ \\
\hline$\beta$-Pinene & 977 & 974 & $2.34 \mathrm{e}$ & $1.63 \mathrm{f}$ & $2.63 \mathrm{c}$ & $4.80 \mathrm{a}$ & $4.36 \mathrm{~b}$ & $2.49 \mathrm{~d}$ \\
\hline 1,8-Cineole & 1033 & 1026 & $17.78 \mathrm{a}$ & $9.72 \mathrm{~d}$ & $15.09 \mathrm{~b}$ & $13.57 \mathrm{c}$ & $17.70 \mathrm{a}$ & $15.13 \mathrm{~b}$ \\
\hline Camphor & 1146 & 1141 & $11.27 \mathrm{a}$ & $3.34 \mathrm{~d}$ & $2.82 \mathrm{e}$ & $9.35 \mathrm{~b}$ & $8.39 \mathrm{c}$ & $9.58 \mathrm{~b}$ \\
\hline Borneol & 1167 & 1165 & $3.13 \mathrm{c}$ & $0.88 \mathrm{e}$ & $1.24 \mathrm{~d}$ & $3.60 \mathrm{a}$ & $3.36 \mathrm{~b}$ & $3.65 \mathrm{a}$ \\
\hline$\delta$-Elemene & 1340 & 1335 & $1.72 \mathrm{~d}$ & $4.81 \mathrm{a}$ & $2.63 \mathrm{~b}$ & $1.30 \mathrm{e}$ & $0.85 \mathrm{f}$ & $2.04 \mathrm{c}$ \\
\hline$\alpha$-Cubebene & 1352 & 1348 & $1.70 \mathrm{~d}$ & $2.21 \mathrm{a}$ & $1.93 \mathrm{~b}$ & $1.54 \mathrm{e}$ & $1.85 \mathrm{c}$ & $1.25 \mathrm{f}$ \\
\hline$\alpha$-Ylangene & 1380 & 1373 & $4.06 \mathrm{a}$ & $3.48 \mathrm{c}$ & $3.24 \mathrm{~d}$ & $3.00 \mathrm{e}$ & $3.61 \mathrm{~b}$ & $2.51 \mathrm{f}$ \\
\hline (E)-caryophyllene & 1427 & 1417 & $5.76 \mathrm{e}$ & $13.28 \mathrm{a}$ & $8.79 \mathrm{~b}$ & $7.24 \mathrm{~d}$ & $5.43 \mathrm{f}$ & $7.57 \mathrm{c}$ \\
\hline Germacrene D & 1487 & 1480 & $1.38 \mathrm{~d}$ & $3.93 \mathrm{a}$ & $2.30 \mathrm{~b}$ & $0.87 \mathrm{e}$ & $0.53 \mathrm{f}$ & $1.57 \mathrm{c}$ \\
\hline Bicyclogermacrene & 1504 & 1500 & $4.96 \mathrm{c}$ & $10.98 \mathrm{a}$ & $7.45 \mathrm{~b}$ & $3.55 \mathrm{~d}$ & $2.46 \mathrm{e}$ & $5.05 \mathrm{c}$ \\
\hline trans-Calamenene & 1529 & 1521 & $4.78 \mathrm{~d}$ & $4.33 \mathrm{e}$ & $5.44 \mathrm{c}$ & $5.60 \mathrm{~b}$ & $5.93 \mathrm{a}$ & $4.23 \mathrm{e}$ \\
\hline Spathulenol & 1587 & 1577 & $14.61 \mathrm{~b}$ & $10.00 \mathrm{~d}$ & $18.89 \mathrm{a}$ & $12.61 \mathrm{c}$ & $15.61 \mathrm{~b}$ & $14.93 \mathrm{~b}$ \\
\hline Caryophyllene oxide & 1597 & 1582 & $4.77 \mathrm{c}$ & $3.90 \mathrm{~d}$ & $5.45 \mathrm{~b}$ & $6.68 \mathrm{a}$ & $5.91 \mathrm{~b}$ & $5.76 \mathrm{~b}$ \\
\hline Viridiflorol & 1601 & 1592 & $1.62 \mathrm{~d}$ & $2.28 \mathrm{~b}$ & $3.50 \mathrm{a}$ & $1.25 \mathrm{f}$ & $1.91 \mathrm{c}$ & $1.48 \mathrm{e}$ \\
\hline
\end{tabular}

Mean values followed by the same lowercase letters in the row do not differ from each other by the Scott-Knott test $(p \leq 0.05)$. IRR-o: Relative Retention Index - observed; IRR-1: Relative Retention Index - literature (Adams, 2017). Source: Authors 
Figure 1. Two dimensional dendrogram that represents the similarity of E. fruticosa populations with the chemical composition of the essential oils.

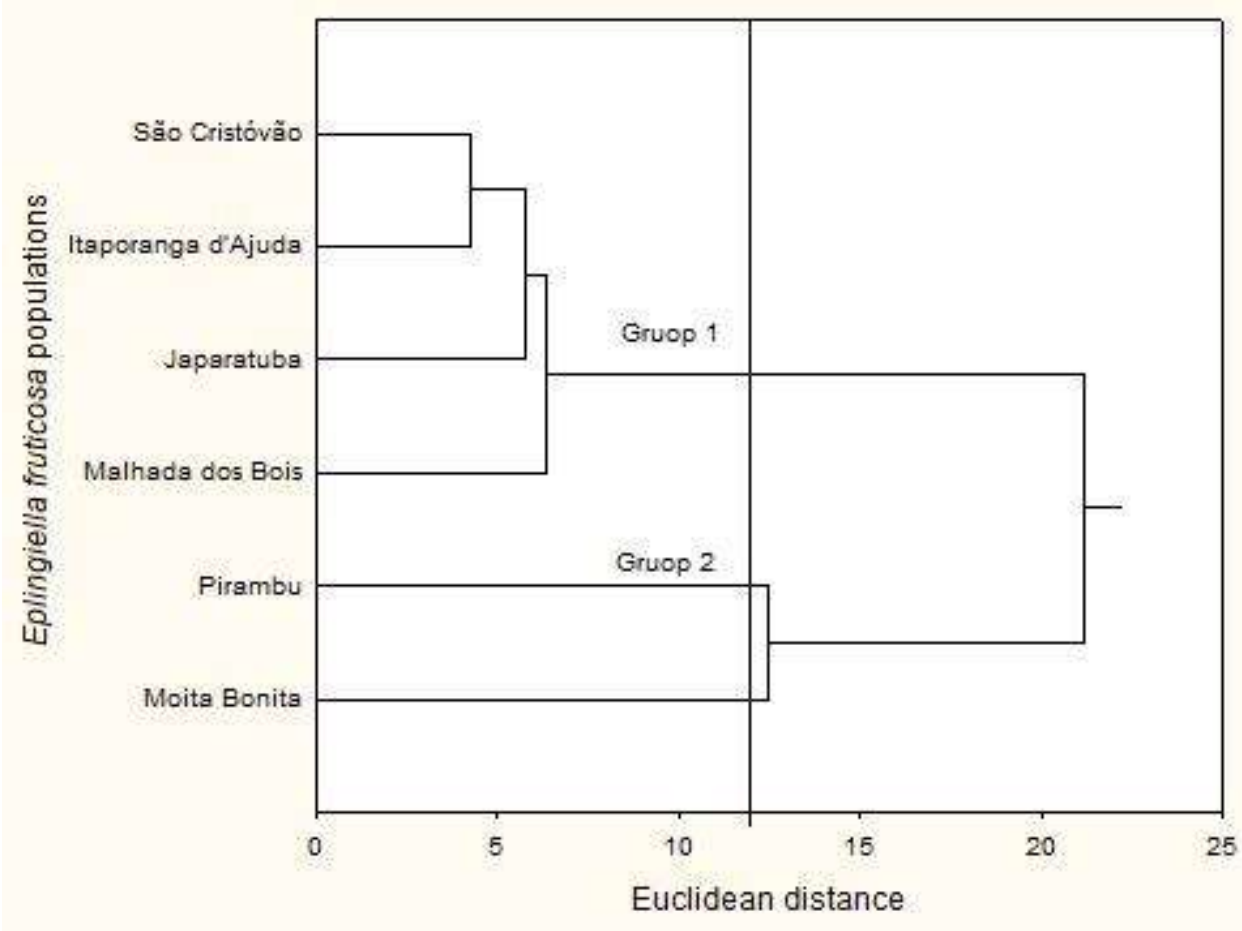

Source: Authors

Figure 2. Distribution of the chemical constituents of the essential oil of E. fruticosa plants in relation to the two principal components through principal component analysis (PCA).

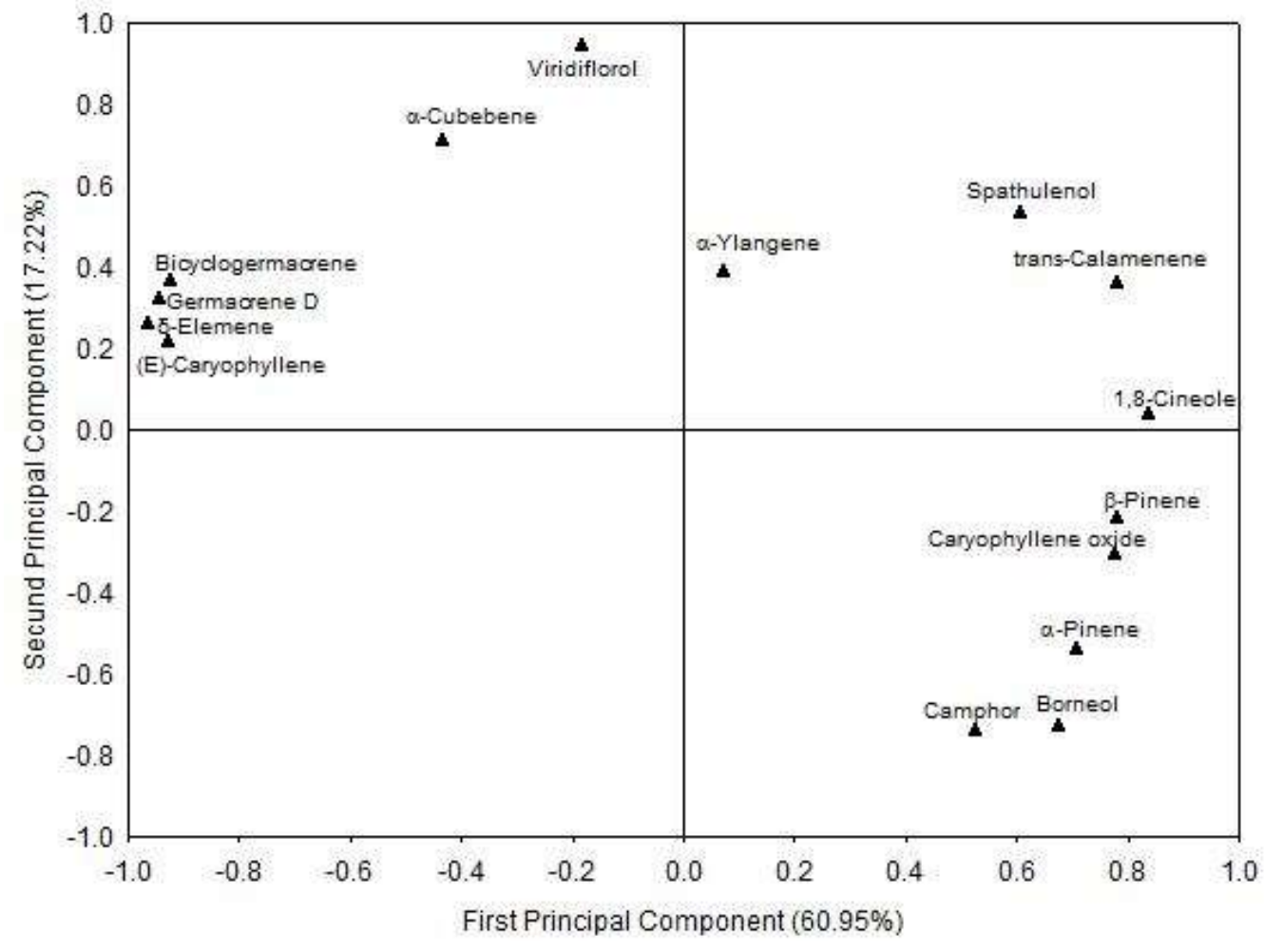

Source: Authors 
Figure 3. Mean values of the main chemical constituents of the essential oils of the E. fruticosa plants, Groups 1 and 2.
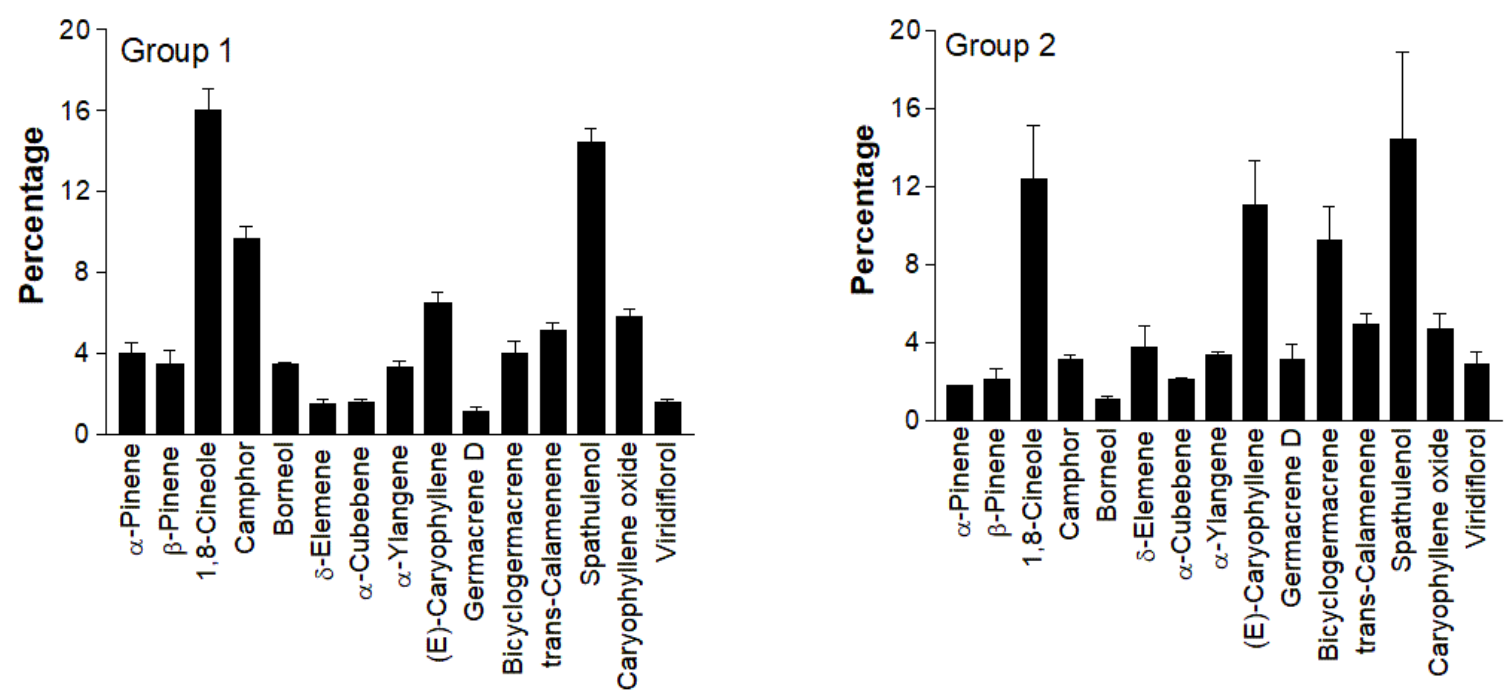

Source: Authors

\subsection{Antioxidant capacity of the essential oils of $E$. fruticosa}

The results of antioxidant activity (DPPH, ABTS, $\beta$-carotene, and FRAP) were reported in Table 2 . The sample from Itaporanga d'Ajuda exhibited the greatest radical scavenging activity (6.96\%) in the DPPH test. In contrast, for the ABTS ${ }^{+}$ radical cation test, the populations of Moita Bonita (3.84\%), Japaratuba (3.40\%), and Pirambu (3.29\%) exhibited activity superior to that of the others.

In the oxidation protection test with $\beta$-carotene, the populations of Pirambu, São Cristóvão, and Malhada dos Bois showed greater capacities of inhibiting lipid peroxidation, with $10.16 \%, 9.50 \%$, and $9.27 \%$, respectively. The capacity for inducing reduction in the iron ion, measured with the FRAP test, was greatest for the sample from Malhada dos Bois, with a value of $206.00 \mu \mathrm{M} / \mathrm{mL}$ (Table 2).

Table 2. Antioxidant activity of the essential oils of E. fruticosa according to the radical capture methods (DPPH and ABTS), $\beta$-carotene/linoleic acid, and iron reduction.

\begin{tabular}{lcccc}
\hline Populations/Municipalities & $\begin{array}{c}\text { DPPH } \\
(\% \text { inhibition })\end{array}$ & $\begin{array}{c}\text { ABTS } \\
(\% \text { inhibition })\end{array}$ & $\begin{array}{c}\beta \text {-carotene } \\
(\% \text { inhibition })\end{array}$ & $\begin{array}{c}\text { FRAP } \\
(\mu \mathrm{M} / \mathrm{mL})\end{array}$ \\
\hline São Cristóvão & $4.16 \pm 0.48^{\mathrm{c}}$ & $1.57 \pm 0.28^{\mathrm{c}}$ & $9.50 \pm 0.08^{\mathrm{a}}$ & $195.86 \pm 0.14^{\mathrm{c}}$ \\
Pirambu & $6.20 \pm 0.31^{\mathrm{ba}}$ & $3.29 \pm 0.37^{\mathrm{a}}$ & $10.16 \pm 0.03^{\mathrm{a}}$ & $110.44 \pm 1.11^{\mathrm{d}}$ \\
Moita Bonita & $3.29 \pm 0.26^{\mathrm{c}}$ & $3.84 \pm 0.17^{\mathrm{a}}$ & $8.10 \pm 0.11^{\mathrm{b}}$ & $203.36 \pm 0.69^{\mathrm{b}}$ \\
Malhada dos Bois & $6.09 \pm 0.25^{\mathrm{ba}}$ & $2.40 \pm 0.14^{\mathrm{b}}$ & $9.27 \pm 0.89^{\mathrm{a}}$ & $206.00 \pm 0.83^{\mathrm{a}}$ \\
Japaratuba & $5.55 \pm 0.19^{\mathrm{b}}$ & $3.40 \pm 0.35^{\mathrm{a}}$ & $5.38 \pm 0.09^{\mathrm{c}}$ & $108.78 \pm 1.11^{\mathrm{d}}$ \\
Itaporanga & $6.95 \pm 0.29^{\mathrm{a}}$ & $1.57 \pm 0.10^{\mathrm{c}}$ & $7.49 \pm 0.25^{\mathrm{b}}$ & $201.42 \pm 0.42^{\mathrm{b}}$ \\
\hline
\end{tabular}

Mean values \pm standard deviation of at least three independent experiments after treatments with the essential oil of $E$. fruticosa. Mean values followed by the same letter in the columns do not differ from each other by Tukey's test ( $p \leq 0.05)$. Source: Authors 


\subsection{Cytotoxicity effect of the essential oils of $E$. fruticosa populations}

The essential oils of E. fruticosa (Figure 4) were evaluated regarding their effect on reduction in cell growth of three lines of tumor cells, A549 (lung cancer), B16F10 (melanoma), and C6 (glioma). Doxorubicin (positive control) showed high growth inhibition in the three tumor lines evaluated (87.14 - 94.63\%). Among the essential oils, the Japaratuba population exhibited greater cytotoxicity in relation to the others for the line A549, with cell inhibition of 51.00\%. In B16F10, the highest degree of inhibition (64.94\%) was observed for the essential oil from the Malhada dos Bois population. There was no difference in C6, and the degree of inhibition ranged from 30.62\% (Malhada dos Bois) to 49.40\% (Japaratuba) (Figure 4).

Figure 4. Degree of growth inhibition in A549, B16F10, and C6 after treatment with essential oil of E. fruticosa populations.

Mean values \pm standard deviation of at least three independent experiments. Mean values followed by the same letter in the columns do not differ from each other by Tukey's test $(p \leq 0.05) .10 \mu \mathrm{M}$ doxorubicin was used as a positive control.

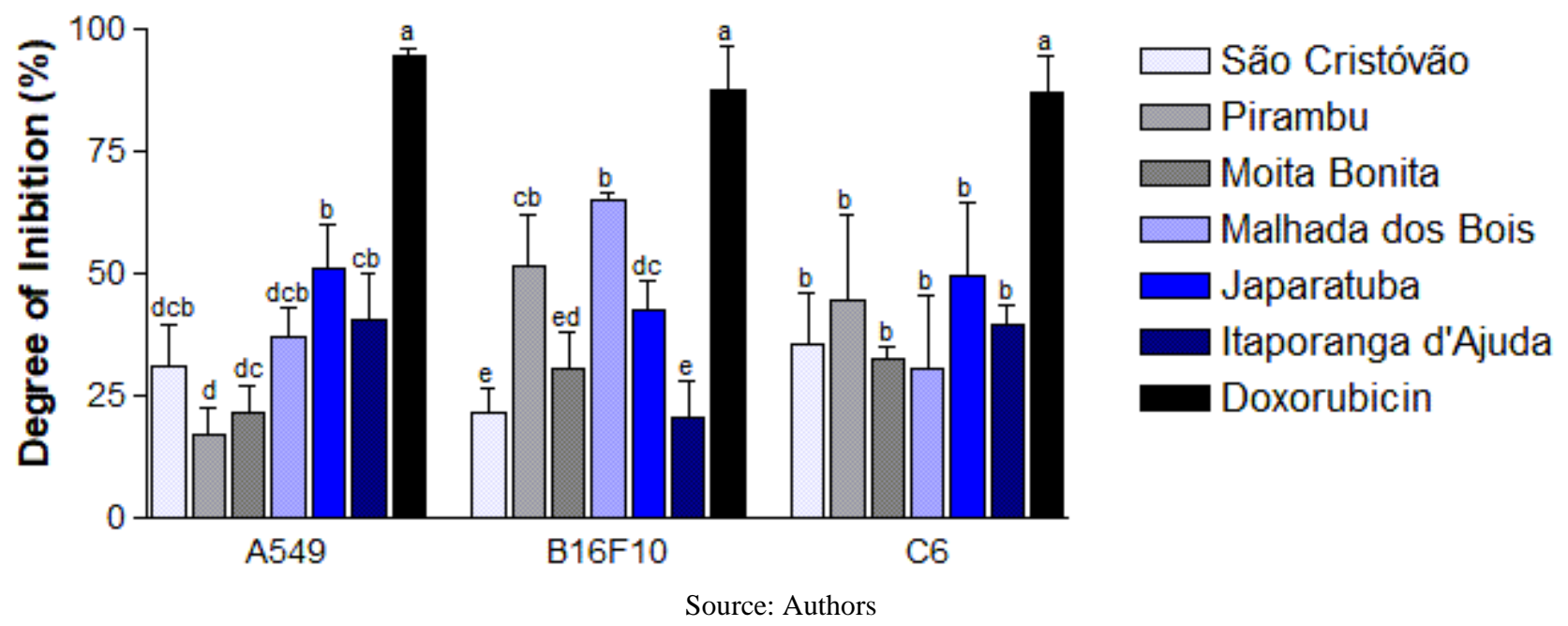

\section{Discussion}

The essential oils of E. fruticosa are characterized by the variability in their components (Silva et al., 2018). This chemical polymorphism results from diverse factors, including genetic and environmental effects that, in combination or independently, affect their composition and quantitative and qualitative properties. The locations where the alecrim-devaqueiro populations were collected have similar topographic, soil, and mean annual temperature characteristics (Silva et al., 2018). Recently, an ecogeographic study of E. fruticosa described a common growth environment of the species, with sandy soils of low fertility and high aluminum $\left(\mathrm{Al}^{+3}\right)$ concentration and content (Oliveira et al., 2021). The small variation observed in the composition of the essential oils among the E. fruticosa populations can be partially attributed to the low phenotypic plasticity of the plants to adapt to different environmental conditions. The limited geographic distribution of this medicinal plant may be a significant explanation of its chemical stability (Silva et al., 2018). Thus, it produces what is necessary for adaptation to the environment in which it occurs. If the environment does not vary, it does not suffer "pressure" to produce other compounds in response to the environment.

In the present study, the terpenoids camphor and bicyclogermacrene were the most representative compounds among the groups formed with the populations. Oliveira Melo et al. (2020) identified 26 compounds in the essential oil of E. fruticosa; the sesquiterpenes (65.7\%), monoterpenes (33.23\%), and the principal components included (E)-caryophyllene (14.16\%), bicyclogermacrene (12.68\%), 1,8-cineole (11.03\%), $\alpha$-pinene (6.79\%), and $\beta$-pinene (5.10\%). The compounds 1,8-cineole, spathulenol, $\alpha$-pinene, and $\beta$-pinene were the principal components found in another study analyzing the composition and 
variability of the essential oil of E. fruticosa (Franco et al., 2011). The monoterpenoids (C10) and the sesquiterpenoids (C15) are widely distributed in the plants and are the most common constituents of volatile compounds in flowers, fruit, stems, and leaves. In addition to playing important roles in plant-environment interactions, many of them also have high commercial value because of their diverse biological activities (Anulika et al., 2016).

All the populations in the study exhibited low antioxidant abilities in the different tests. The antioxidant activity of an essential oil depends on its chemical composition. A good antioxidant response can be expected from essential oils with a large phenolic content and a modest unsaturated terpene content (Amorati et al., 2013; Miguel, 2010). Phenolic compounds have redox properties and therefore play an important role in the neutralization of free radicals (Dhifi et al., 2016). Therefore, the weak antioxidant activity of the oils of E. fruticosa may be attributable to their not having phenolic compounds in their composition. In a study with essential oils of Ocimum kilimandscharicum populations, greater antioxidant activity was identified in the plants with the presence of phenylpropanoids (eugenol, methyl chavicol) compared to populations predominated by terpenes, such as camphor (Chaturvedi et al., 2018). The same characteristic was observed in Ocimum basilicum, where the cultivars with the best antioxidant performance were characterized by those with essential oils rich in eugenol (Couto et al., 2019).

This is the first study regarding the antioxidant and cytotoxicity activities of the essential oil of E. fruticosa. The populations from Japaratuba and Malhada dos Bois stood out with the highest degrees of inhibition in A549 and B16F10, respectively. Their oils are found in Group 1, in which camphor stood out as the compound with the highest concentration in relation to the populations of Group 2. Currently, the anticancer activity of various natural compounds derived from plants, such as essential oils, has been tested (Kaushik; DeBerardinis, 2018). Essential oils of Chiliadenus antiatlanticus, which have camphor as the major component in their constitution, showed significant toxicity for liver tumor cell lines HepG2 (55.8\% cell inhibition) and melanoma B16 4A5 (41.6\% cell inhibition) at $100 \mu \mathrm{g} / \mathrm{mL}$ (El Yaagoubi et al., 2021). Coté et al. (2017) evaluated the cytotoxic activity of the essential oil of Tanacetum vulgare and its principal components and identified the cytotoxic effect against A549 lung cancer with concentrations greater than $200 \mu \mathrm{g} / \mathrm{mL}$ of the essential oil, whereas the main constituents of camphor, borneol, and 1,8-cineole were all inactive at concentrations greater than $200 \mu \mathrm{g} / \mathrm{mL}$.

The mechanisms involved in antiproliferative activity mediated by essential oils include a halt in the cell cycle, apoptosis, and DNA repair mechanisms. The essential oils also act in reducing tumors, inhibiting metastases, and as antimultiresistance to medication molecules (Mesquita et al., 2019). Nevertheless, the great variation in the chemical profile of the essential oils means great diversity in the mechanisms of action and molecular targets. In addition, as these oils consist of a wide variety of compounds, each one of them can modulate or alter the effects of the others.

\section{Conclusion}

As a result in this study, little variation was observed in the composition of the essential oils among the E. fruticosa populations. Fifty-one compounds were found; $\alpha$-pinene, $\beta$-pinene, 1,8-cineole, camphor, borneol, $\delta$-elemene, $\alpha$-cubebene, $\alpha$ ylangene, (E)-caryophyllene, germacrene D, bicyclogermacrene, trans-calamenene, spathulenol, caryophyllene oxide, and viridiflorol were the main metabolites. The plants showed weak effects in terms of antioxidant activity; however, the populations of Japaratuba and Malhada dos Bois exhibited moderate cytotoxicity for cell lines of A549 and B16F10, which may be related to the presence of the monoterpene camphor. More studies are needed to elucidate the role those different components of the essential oil of E. fruticosa play in cytotoxicity for cell lines alone or in combination. 


\section{Acknowledgments}

This study was funded, in part, by Brazil's Conselho Nacional de Desenvolvimento Científico e Tecnológico (CNPq), the Fundação de Apoio à Pesquisa e a Inovação Tecnológica do Estado de Sergipe (Fapitec/SE), the Coordenação de Aperfeiçoamento de Pessoal de Nível Superior (CAPES, Finance Code 001), and the Financiadora de Estudos e Projetos (FINEP).

\section{References}

Adams, R. P. (2017). Identification of essential oils components by gas chromatography/quadrupole mass spectrometry. Allured Publishing Cooperation, Illinois, USA.

Amorati, R., Foti, M.C., Valgimigli, L. (2013). Antioxidant activity of essential oils. Journal of Agricultural and Food Chemistry, 61(46), $10835-10847$.

Anulika, N. P., Inácio, E.O., Raymond, E. S., Osasere, O.I., Abiola, A.H. (2016). The chemistry of natural product: Plant secondary metabolites. International Journal of Technology Enhancements and Emerging Engineering Research, 4(8), 1-8.

Beserra-Filho, J. I. A, Macêdo, A. M., Leão, A. H. F. F., Bispo, J. M. M., Santos, J. R., Oliveira-Melo, A. J., Menezes, P. P., Duarte, M. C., Araújo, A. A. S., Silva, R.H., Quintans-Júnior, L.J., Ribeiro, A.M. (2019). Eplingiella fruticosa leaf essential oil complexed with $\beta$-cyclodextrin produces a superior neuroprotective and behavioral profile in a mice model of Parkinson's disease. Food and Chemical Toxicology, 124, 17-29.

Brand-Williams, W., Cuvilier, M.E., Berset, C. (1995). Use of a free radical method to evaluate antioxidant activity. Lebensmittel-Wissenschaft Technologie, $28(1), 25-30$

Bray, F., Ren, J. S., Masuyer, E., Ferlay, J. (2013). Global estimates of cancer prevalence for 27 sites in the adult population in 2008. International Journal of Cancer, 132(5), 1133-1145.

Chaturvedi, T., Kumar, A., Kumar, A., Verma, R.S., Padalia, R.C., Sundaresan, V., Chauhan, A., Saikia, D., Singh, V.R., Venkatesha, K.T. (2018). Chemical composition, genetic diversity, antibacterial, antifungal and antioxidant activities of camphor-basil (Ocimum kilimandscharicum Guerke). Industrial Crops and Products, 118, 246-258

Coté, H., Boucher, M. A., Pichette, A., Legault, J. (2017). Anti-inflammatory, antioxidant, antibiotic, and cytotoxic activities of Tanacetum vulgare L. essential oil and its constituents. Medicines, 4(2), 34 .

Couto, H. G. S. A., Blank, A. F., Silva, A. M. D. O., Nogueira, P. C. L., Arrigoni-Blank, M. F., Nizio, D. A. C., Pinto, J. A. O. (2019). Essential oils of basil chemotypes: major compounds, binary mixtures, and antioxidant activity. Food Chemistry, 293, 446-454.

Dhifi, W., Bellili, S., Jazi, S., Bahloul, N., Mnif, W. (2016). Essential oils' chemical characterization and investigation of some biological activities: A critical review. Medicines, 3(4), 25.

Ehlert, P. A. D., Blank, A. F., Arrigoni-Blank, M. F., Paula, J. W. A., Campos, D. A., Alviano, C. S. (2006). Tempo de hidrodestilação na extração de óleo essencial de sete espécies de plantas medicinais. Revista Brasileira de Plantas Medicinais, 8(2), 79-80.

El Yaagoubi, M., Ortiz, S., Mechqoq, H., Cavaleiro, C., Lecsö-Bornet, M., Rodrigues, M.J., Custódioe, L., El Mousadika, A., Grougnet, R., El Aouada, N., Msanda, F., Kritsanida, M. (2021). Chemical composition, antibacterial screening and cytotoxic activity of Chiliadenus antiatlanticus (Asteraceae) essential oil. Chemistry \& Biodiversity, 18(6), 2100115.

Ferreira, D. F. (2011). Sisvar: a computer statistical analysis system. Ciência e agrotecnologia, 35, 1039-1042.

Franco, C. R. P., Antoniolli, Â. R., Guimarães, A. G., Andrade, D. M., Jesus, H. C. R., Alves, P. B., Bannet, L. E ., Patrus, A. H., Azevedo, E. G., Queiroz, D. B., Quintans, L. J. (2011). Bioassay-guided evaluation of antinociceptive properties and chemical variability of the essential oil of Hyptis fruticosa. Phytotherapy Research, 25(11), 1693-1699.

Guenther, E. (1972). The essential oils: volume three - individual essential oils of the plant families Rutaceae and Labiatae. Malabar: Krieger. 777p.

Harley, R. M., Pastore, J. (2012). A generic revision and new combinations in the Hyptidinae (Lamiaceae), based on molecular and morphological evidence. Phytotaxa, 58(1), 1-55.

Kasinski, A. L., Kelnar, K., Stahlhut, C., Orellana, E., Zhao, J., Shimer, E., Dysart, S., Chen, X., Bader, A. G., Slack, F. J. (2015). A combinatorial microRNA therapeutics approach to suppressing non-small cell lung cancer. Oncogene, 34(27), 3547-3555.

Kaushik, A. K., Ralph, J.D. (2018). Applications of metabolomics to study cancer metabolism. Biochimica et Biophysica Acta (BBA)-Reviews on Cancer, 1870(1), 2-14.

Jamshidi-Kia, F., Lorigooini, Z., Amini-Khoei, H. (2018). Medicinal plants: past history and future perspective. Journal of herbmed pharmacology, 2018(1), $1-7$.

Jemli, M. E., Kamal, R., Marmouzi, I., Zerrouki, A., Cherrah, Y., Alaoui, K. (2016). Radical-scavenging activity and ferric reducing ability of Juniperus thurifera (L.), J. oxycedrus (L.), J. phoenicea (L.) and Tetraclinis articulata (L.). Advances in pharmacological sciences, 2016, 1-6. 
Leporini, M., Bonesi, M., Loizzo, M.R., Passalacqua, N.G., Tundis, R. (2020). The essential oil of Salvia rosmarinus Spenn. from Italy as a source of healthpromoting compounds: Chemical profile and antioxidant and cholinesterase inhibitory activity. Plants, 9(6) 798.

Mesquita, L. S. S. D., Luz, T. R. S. A., Mesquita, J. W. C. D., Coutinho, D. F., Amaral, F. M. M. D., Ribeiro, M. N. D. S., Malik, S. (2019). Exploring the anticancer properties of essential oils from family Lamiaceae. Food Reviews International, 35(2), 105-131.

Miguel, M. G. (2010). Antioxidant and anti-inflammatory activities of essential oils: a short review. Molecules, 15(12), 9252-9287.

Miller, H. E. (1971). A simplified method for the evaluation of antioxidants. Journal of the American Oil Chemists' Society, 48(2), 91.

Nieto, G. (2017). Biological activities of three essential oils of the Lamiaceae family. Medicines, 2017(3), 63.

Oliveira, E. A., Oliveira, L. M., Lordelo, M. S., Sales, R. P. (2021). Ecogeographic studies on Eplingiella fruticosa (Salzm. Ex Benth. Harley\& J.F.B. Pastore: A medicinal species of the semiarid region of Brazil. Research, Society and Development, 10(4), e37610413963.

Oliveira Melo, A.J., Heimarth, L., dos Santos Carvalho, A. M., Quintans, J. D. S. S., Serafini, M. R., de Souza Araújo, A. A., Alves, P. B., Ribeiro, A. M., Shanmugam, S., Quintans-Júnior, L. J., Duarte., M. C. (2020). Eplingiella fruticosa (Lamiaceae) essential oil complexed with $\beta$-cyclodextrin improves its antihyperalgesic effect in a chronic widespread non-inflammatory muscle pain animal model. Food and Chemical Toxicology, 135, 110940.

Orellana, E., Kasinski, A. (2016). Sulforhodamine B (SRB) assay in cell culture to investigate cell proliferation. Bio-Protocol, $2016(21)$, e1984.

Re, R., Pellegrini, N., Proteggente, A., Pannala, A., Yang, M., Rice-Evans, C. (1999). Antioxidant activity applying an improved ABTS radical cation decolorization assay. Free radical biology and medicine, 26(9-10), 1231-1237.

Sharifi-Rad, J., Sureda, A., Tenore, G. C., Daglia, M., Sharifi-Rad, M., Valussi, M., Tundis, R., Sharifi-Rad, M., Loizzo, M. R., Ademiluyi, A. O., Sharifi-Rad, R., Ayatollahi, S.A., Sharifi-Rad, R. (2017). Biological activities of essential oils: From plant chemoecology to traditional healing systems. Molecules, 22(1), 70.

Silva, D. C., Diniz, L. E. C., Blank, A. F., Nizio, D. A. C., Pinto, J. A. O., Pereira, K. L. G., Arrigoni-Blank, M. F. (2017). Assessment of genetic diversity of a native population of Eplingiella fruticosa: a plant with therapeutic potential. Genetics and Molecular Research, 16, 1-10.

Silva, D. C., Blank, A. F., Nizio, D. A. C., Sampaio, T. S., Nogueira, P. C. L., Arrigoni-Blank, M. F. (2018). Chemical diversity of essential oils from native populations of Eplingiella fruticosa. Crop Breeding and Applied Biotechnology, 18, 205-214.

Singhal, M., Paul, A., Singh, H. P. (2014). Synthesis and reducing power assay of methyl semicarbazone derivates. Journal of Saudi Chemical Society, 18(2), 121-127.

Sivakumar, T., Balasubramanian, S. (2020). A review on some folk medicinal plants and their common uses. Research Biotica, 2(4), $131-134$.

Sousa, E.O., Rocha, J.B., Barros, L.M., Barros, A.R., Costa, J.G. (2013). Phytochemical characterization and in vitro antioxidant properties of Lantana camara L. and Lantana montevidensis Briq. Industrial Crops and Products, 43, 517-522.

Tariq, A., Sadia, S., Pan, K., Ullah, I., Mussarat, S., Sun, F., Abiodun, O., Batbaatar, A., Li, Z., Song, D., Xiong, Q., Ullah, R., Khan, S., Basnet, B., Kumar, B., Islam, R., Adnan, M. (2017). A systematic review on ethnomedicines of anti-cancer plants. Phytotherapy Research, 31(2), 202-264.

Uritu, C. M., Miha, C. T., Stanciu, G. D., Dodi, G., Alexa-Stratulat, T., Luca, A., Leon-Constantin, M. M., Stefanescu, R., Bild, V., Melnic, S., Tamba, B. I. (2018). Medicinal plants of the family Lamiaceae in pain therapy: A review. Pain Research and Management, 44p.

Van Den Dool, H., Kratz, P. D. (1963). A generalization of the retention index system including linear temperature programmed gas-liquid partition chromatography. Journal of Chromatography A, 11, 463-471. 